\title{
Dorota Grabowska-Pieńkosz*
}

Toruń

\section{Religie w dialogu kultur. V Międzynarodowy Kongres Religioznawczy, Toruń, 14-16 września 2017 roku (sekcja XIX)}

Pod hasłem „Religie w dialogu kultur” w dniach 14-16 września 2017 roku odbył się V Międzynarodowy Kongres Religioznawczy, już po raz drugi w Toruniu. Jego organizatorami byli: Polskie Towarzystwo Religioznawczego (PTR), Uniwersytet Mikołaja Kopernika (Wydział Politologii i Studiów Międzynarodowych, Wydział Nauk Pedagogicznych, Wydział Teologiczny), a także Fundacja Societas et Ius. Ideą kongresu uczyniono dialog, który stanowi podstawę egzystencji człowieka. Jak podkreślił Prezes PTR, Jerzy Kojkoł: „Religie wnoszą do współczesnego społeczeństwa duży potencjał dla dialogu, mogą dawać głębokie fundamenty dialogiczności, wskazując na swoistą wrażliwość człowieka skierowaną ku inności. Pamiętamy jednocześnie, że współcześnie dialog wydaje się stawać z jednej strony zjawiskiem uniwersalnym i powszechnym oraz wieloaspektowym, z drugiej wciąż partykularnym i jednowymiarowym". Podczas kongresu odbyły się trzy sesje plenarne pod następującymi tytułami: „Protestantyzm - religia - wolność”, „Religia - nauka - dialog”, „Współczesne imitacje religii”, panel dysku-

* Dr Dorota Grabowska Pieńkosz jest adiunktem w Katedrze Historii Myśli Pedagogicznej na Wydziale Nauk Pedagogicznych Uniwersytetu Mikołaja Kopernika w Toruniu. Adres: Wydział Nauk Pedagogicznych UMK, ul. Lwowska 1, 87-100 Toruń; e-mail: dogra@umk.pl.

1 Jerzy Kojkoł, „Idea Kongresu”, w: Religie w dialogu kultur, red. Marek Szulakiewicz (Toruń, 2017), 13. 
syjny pt. „Religie w kulturze współczesnej” oraz 24 sekcje: „Dziedzictwo kulturowe reformacji”; „Reformacja - oświata i kształcenie”; „Reformacyjne dziedzictwo polskiego środowiska ewangelikalnego"; „Nowe problemy filozofii religii”; „Historia i teoria religii”; „Aksjologia religii”; „Antropologia religii”; „Religia a nauka”; „Religijność Europy i świata”; „Socjologia religii”; „Religie w poszukiwaniu nowej duchowości”; „Edukacja religijna dla kultury dialogu”; „Religie wschodu i zachodu. Interakcje”; „Muzułmanie w Europie i Ameryce”; „Religia a polityka”; „Dialog międzyreligijny”; „Biblia w dialogu kultur i wyznań”; „Badania nad językiem religijnym”; „Religie a wychowanie do dialogu”; „Tradycja w katolicyzmie i protestantyzmie”; „Media a religia”; „Poezja a religia”; „Mythological and religious motives in world cultures”; „Metafizyka religii”.

W dniu 15 września 2017 roku obrady rozpoczęła sekcja XIX, której hasłem przewodnim było: „Religie a wychowanie do dialogu”. Przewodniczył jej ks. prof. dr Mirosław Stanisław Wierzbicki z Università Pontificia Salesiana w Rzymie. Podejmowana problematyka dotyczyła szeroko rozumianego religioznawstwa, ekumenizmu, wychowania religijnego w nawiązaniu do przeszłości, jak i wskazano współczesne problemy pojawiające się w różnych kulturach na świecie. Przewodniczący podkreślił, że podstawę ludzkiej egzystencji stanowi wychowanie oraz dialog pomiędzy kulturami i religiami. Szczególnie religie mogą wnieść do współczesnego społeczeństwa duży potencjał w zakresie rozwoju i wychowania człowieka. Dlatego jak zaznaczył: „Wychowanie do dialogu wymaga więc dojrzałej i twórczej osobowości, odpowiednich kompetencji komunikacyjnych w tworzeniu klimatu, wzbudzaniu zaufania, życzliwości, otwartości, akceptacji drugiego człowieka oraz pasji wychowawczej"2.

Pierwszą część obrad rozpoczął dr hab. Witold Glinkowski, prof. UŁ, który przybliżył kwestię: „Religia jako dialog człowieka z Bogiem”. W wystąpieniu nawiązał do propozycji i tradycji współczesnej filozofii dialogu. Zaakcentował, że w relacji religijnej niezwykle ważną rolę odgrywa więź między dwoma partnerami, a mianowicie człowiekiem i Bogiem, która ma charakter dialogu. Kolejny referat: „Wychowanie religijne w rodzinie. Dwugłos Lucyny Mieroszewskiej i Stefanii Marciszewskiej-Posadzowej" wygłosiła dr Joanna Falkowska. W nawiązaniu do poglądów tych myślicielek podkreśliła, że szczególną rolę w wychowaniu religijnym w okresie zaborów odegrała rodzina, a przede wszystkim matka. W wychowaniu młodego po-

2 Mirosław Wierzbicki, „Sekcja XIX: Religie a wychowanie do dialogu”, w: Religie $w$ dialogu kultur, red. Marek Szulakiewicz (Toruń, 2017), 248. 
kolenia religia stanowiła ważny element, który wpływał na kształtowanie jego osobowości, a także sprzyjał rozwojowi takich wartości, jak tolerancja i otwartość na dialog. Następnie głos zabrał dr Celestine Arinze Okafor. W wystąpieniu pt. „Religia i kultura w szkołach katolickich w Nigerii” zwrócił uwagę na konieczność wychowania do dialogu w nigeryjskich szkołach katolickich, a w szczególności dążenia do integracji wiary i kultury. Wielu obywateli tego kraju wzywa do dialogu między dwiema religiami, tj. islamem i chrześcijaństwem, aby zapobiec przemocy religijnej i znaleźć płaszczyznę porozumienia. Z kolei dr Jeannette Lugerero zaprezentowała „Kulturę Kongo w dialogu międzyreligijnym”. Prelegentka przybliżyła kulturę i tradycję religijną tego państwa. Podkreśliła, że kultura kongijska charakteryzuje się wielokulturowością, a zarazem głęboką wiarą i otwartością religijną, co sprzyja rozwojowi różnych religii, m.in. katolicyzmu, protestantyzmu czy islamu. Ponadto mieszkańcy dbają o kulturę i multireligijność poprzez dialog, który stanowi swoisty pomost między plemionami, a szczególnie między religiami. Następnie uczestnicy wysłuchali wystąpienia prof. dr hab. Władysławy Szulakiewicz pt. „Znaczenie religii w kształceniu charakteru człowieka. Analiza wybranych koncepcji”. Zwróciła ona uwagę, że kształcenie charakteru powinno stanowić podstawę wychowania moralnego i religijnego człowieka. Poprzez odwołanie się do wybranych publikacji pedagogicznych, filozoficznych, psychologicznych przedstawiła rolę religii w życiu człowieka.

Drugą część obrad otworzył referat dr Aldony Zakrzewskiej pt. „Wielorakość kulturowo-religijna a wychowanie obywatelskie w szkole katolickiej”. Prelegentka przedmiotem swoich rozważań uczyniła wychowanie obywatelskie realizowane w szkołach katolickich, którego celem jest kształtowanie postawy otwartości młodego pokolenia na różnorodność kulturową i religijną. Zaznaczyła, że jest to bardzo trudne zadanie, ponieważ mimo tego, że szkoły te deklarują budowanie jedności w różnorodności, to jednak proces dydaktyczno-wychowawczy determinuje dany światopogląd. Z kolei dr Eakarat Hompratum zaprezentował zagadnienie dotyczące „Dialogu międzyreligijnego z buddystami w Tajlandii”. Podkreślił, że kultura tego kraju została zdominowana przez buddyzm, lecz dopiero Sobór Watykański II przyczynił się do wypracowania nowego stylu współpracy między różnymi religiami. Współcześnie w Tajlandii niezwykle ważne jest budowanie wzajemnego zrozumienia i współpracy między chrześcijanami a buddystami. Następnie uczestnicy sekcji wysłuchali wystąpienia dr. Krzysztofa Pilarza pt. „Małżeństwo i rodzina w tyglu religii i ideologii”. Prelegent zwrócił uwagę na postrzeganie małżeństwa i rodziny w kontekście współczesnych 
paradygmatów antropologicznych i aksjologicznych, z uwzględnieniem światopoglądów religijnych. Przybliżył kwestię tożsamości jednostek tworzących małżeństwo w kontekście budowania związku osobowego i dążenia do dialogiczności. Z kolei mgr Francis Onyebuchi Unegbu przedstawił problematykę „Formacji integralnej w szkołach w obliczu dialogu z kulturą”. Podkreślił znaczenie szkoły w formowaniu osobowości młodych ludzi. Poza tym wskazał na potrzebę integralnej i holistycznej edukacji w przygotowaniu charakteru i pozytywnego zaangażowania obywatelskiego młodzieży. Następnie głos zabrała dr hab. Elżbieta Osewska, prof. PWSZ w Tarnowie. Jej rozważania dotyczyły „Wychowania do wiary i dialogu”, a w szczególności omówiła kwestię odpowiedzialności w wychowaniu ludzi do wiary we współcześnie zmieniającym się świecie, a także otwartości na dialog między różnymi religiami i kulturami. Tę część obrad zamykało wystąpienie ks. prof. dr. Mirosława Wierzbickiego pt. „Edukacja do dialogu w szkolnictwie włoskim". Prelegent wskazał kierunki badań nad tożsamością i misją szkół włoskich, ich udziałem w zmianach o charakterze społecznym i edukacyjnym w zakresie dialogu międzykulturowego i międzyreligijnego.

W czasie obrad sekcji pt. „Religie a wychowanie do dialogu” poruszono wiele istotnych kwestii dotyczących wychowania do dialogu w różnych religiach i kulturach, z perspektywy filozoficznej, pedagogicznej, psychologicznej, socjologicznej. Podkreślono znaczenie postawy człowieka wobec Boga, samego siebie, drugiego człowieka i tworzonej przez niego kultury. Zastanawiano się nad rolą wychowania religijnego w różnych kulturach i grupach społecznych, a także nad znaczeniem edukacji religijnej w zmieniających się warunkach społeczno-politycznych i ekonomicznych. Odwołano się do przeszłości, jak i wskazano współczesne tendencje w zakresie wychowania do dialogu i miejsca religii w życiu człowieka. Z bogactwa zaprezentowanych treści wynika, że wychowanie do dialogu wymaga dojrzałej i twórczej osobowości, życzliwej i otwartej na drugiego człowieka oraz jego świat wartości. 